perspektyw przedstawia omawiane zagadnienia. Dzięki temu udało mu się w intrygujący sposób, przedstawić temat wielokrotnie poruszany, a mimo to nieopracowany kompleksowo. $\mathrm{Z}$ tego powodu omawiana praca jest niezwykle wartościowa, gdyż całościowo przedstawia dzieje Departamentu Stanu, a takiego ujęcia wspomnianego zagadnienia brakowało w literaturze polskiej. Niewątpliwą zaletą recenzowanej publikacji jest także jej przystępność w odbiorze przez wszystkich, zainteresowanych tematyką polityki zagranicznej USA czy funkcjonowaniem administracji federalnej.

Katarzyna Chomicz

Wydział Historyczno-Socjologiczny

Uniwersytet w Białymstoku

\title{
Irakli Matcharashvili, 2008 rok, Wojna rosyjsko-gruzińska. Wojna która nie wstrząsnęła światem, NapoleonV, Oświęcim 2013, ss. 271
}

Autorem publikacji jest Irakli Matcharashvili - urodzony w Tbilisi absolwent gruzińskiego Korpusu Kadetów, brytyjskiego National Security College i Wydziału Historycznego Uniwersytetu im. Adama Mickiewicza w Poznaniu. Weteran Francuskiej Ligii Cudzoziemskiej. Autor specjalizuje się w historii wojskowości drugiej połowy XX wieku, a także w problematyce współczesnej Rosji oraz państw Kaukazu. Recenzowana publikacja jest poprawioną i zaktualizowaną wersją dysertacji doktorskiej - pisanej pod kierunkiem dr hab. Prof. UAM Macieja Franza - którą autor obronił w Instytucie Historii UAM w 2011 roku.

Problematyka wojny rosyjsko-gruzińskiej została już dość szczegółowo opracowana zarówno w literaturze polskojęzycznej, jak i zagranicznej. Z publikacji w języku polskim warto wymienić chociażby książkę Radosława Grodzkiego Wojna gruzińsko-rosyjska 2008: przyczyny, przebieg, skutki, pracę pod redakcją Roberta Potockiego, Marcina Domagały, Przemysława Sieradzana - Konflikt kaukaski w 2008 roku czy publikację Akademii Marynarki Wojennej - Konflikt rosyjsko-gruziński w 2008 roku. Z publikacji zagranicznych nie można zapomnieć o książkach: The great power (mis)management: the Russian-Georgian war and its implications for global political order autorstwa Alexandera Astrova, The guns of August 2008; Russia's war in Georgia napisane przez Svante E. Cornella i Fredericka Starr oraz A little war that shook the world: Georgia, Russia and the future of the West Ronalda D. Asmusa. Z literatury rosyjskojęzycznej warto wspomnieć o publikacji Анатолия Цыганока Война 08.08.08. Принуждение Грузии к миру. Książki te stanowią przede wszystkim analizę wydarzeń, które miały miejsce podczas wojny rosyjsko-gruzińskiej w 2008 roku. Charakteryzują się dość wysokim stopniem ogólnikowości, ale 
są przy tym rzetelne i stanowią wiarygodne źródło wiedzy na temat omawianego konfliktu.

Praca I. Matcharashvilego ma przede wszystkim pokazać gruzińskie spojrzenie na wojnę z 2008 roku, co odróżnia ją od innych publikacji na ten temat. Ma stanowić także swego rodzaju manifest wobec świata, ukazujący, że nie poświęcił on dostatecznej uwagi wojnie w Gruzji (s. 10). Autor deklaruje, że jego zamierzeniem nie jest wyłączne przedstawienie gruzińskiej wersji wydarzeń. Pragnie on ująć konflikt z 2008 roku w sposób całościowy, charakteryzując jego przyczyny, przebieg i skutki. Podejmuje również próbę obiektywnego podejścia do opisywanych przez siebie wydarzeń.

Analizując publikację I. Matcharashvilego pod względem formalnym, należy zauważyć, iż praca składa się z pięciu powiązanych ze sobą rozdziałów ${ }^{1}$, 40 stron aneksów oraz 70 stron ilustracji. Nie sposób nie zwrócić uwagi na to, iż struktura pracy jest niezborna. Po pierwsze, pierwszy rozdział liczy 46 stron, a pozostałe są wyraźnie krótsze - należałoby zatem rozdzielić pierwszy rozdział na dwa mniejsze. Po drugie, około 45 procent książki stanowią aneksy i ilustracje, co w sposób wyraźny zaburza jej strukturę. Takie dobranie proporcji (między tekstem głównym a aneksami i ilustracjami), wydaje się świadczyć o jej nienaukowym charakterze. Dowodem na to jest również brak wyraźnie i jednoznacznie sformułowanych tez, celów i problemów badawczych. Można pokusić się więc o twierdzenie, iż praca ta ma charakter popularno-naukowy, a jej głównym celem jest poruszenie czytelnika. Tezę tę umacnia fakt, iż istniejąca w książce baza przypisowa jest skąpa i obejmuje głównie przypisy źródłowe.

Ponadto, niektóre informacje stanowiące treść rozdziałów, zostają powtórzone w aneksach. Przykładem tego jest np. rozdział II, który został w całości poświęcony charakterystyce sił zbrojnych stron konfliktu. Co więcej, również $\mathrm{w}$ aneksach zamieszczono dokładny spis jednostek biorących udział w wojnie. Powtarzanie tych samych informacji w dwóch miejscach wydaje się nie tylko niepotrzebne, ale również pozbawione głębszego sensu.

Kolejną kwestią budzącą wątpliwości jest podtytuł książki, który brzmi: Wojna, która nie wstrzqsnęła światem. Zdanie to nie znajduje jednak żadnego odzwierciedlenia w całości publikacji. Jedynie we wstępie znajdujemy stwierdzenie, że podczas konfliktu z 2008 roku świat zapomniał o Gruzji. Należałoby zastanowić się, dlaczego Autor nie pokusił się o analizę otoczenia międzynarodowego konfliktu. Zapewne uznał, że temat ten został wyczerpany przez innych autorów piszących o wojnie rosyjsko-gruzińskiej lub, iż konflikt ten nie miał żadnego wpływu na sytuację międzynarodową. Faktem jest, że większość publikacji dotyczących wojny w Gruzji zawiera rozdziały dotyczące wpływu konfliktu na politykę poszczególnych państw. Książka A. Astrova - The great po-

1 I - Historyczne tło konfliktu, II - Siły zbrojne stron konfliktu, III - Wojna, IV - Straty stron konfliktu, V - Świadectwa, relacje i opinie. 
wer (mis)management: the Russian-Georgian war and its implications for global political order w całości stanowi analizę zależności między wydarzeniami z 2008 roku a polityką Stanów Zjednoczonych, państw NATO, UE i krajów azjatyckich. W A little war that shook the world: Georgia, Russia and the future of the West R. D. Asmusa również znajdujemy rozdział pt. „Gruzja, Rosja i przyszłość Zachodu". Także publikacje w języku polskim nie pomijają kwestii wpływu wojny w Gruzji na otoczenie międzynarodowe i działań podejmowanych przez poszczególne rządy w celu zakończenia konfliktu. Na podstawie przytaczanych przeze mnie publikacji można stwierdzić, iż wojna 2008 roku może i faktycznie nie wstrząsnęła światem, ale na pewno go dość intensywnie poruszyła.

Największym zarzutem, jaki można postawić I. Machtarashvilemu, jest w mojej opinii - jego swoisty brak obiektywizmu. Kilkakrotnie deklaruje on chęć przedstawienia wiarygodnych i prawdziwych wydarzeń, jednak skupia się głównie na stratach poniesionych przez Gruzję. Część faktów, które w swoich publikacjach opisali R. Grodzki czy S. E. Cornell i F. Starr stawiających Gruzję w złym świetle, została przez I. Matcharashvilego po prostu przemilczana. Dobrym przykładem obrazującym ten proceder jest kwestia roli Moskwy w szkoleniu oraz uzbrajaniu wojsk abchaskich i osetyjskich. Jest to wielokrotnie podkreślane przez Matcharashvilego. Nie wspomina on jednak o udziale Waszyngtonu w programie GSSOP (w ramach którego szkolono gruzińskiej wojska), czy pomocy finansowej $z$ Turcji i USA. Informacje te znajdujemy w większości publikacji dotyczących wojny w Gruzji - w publikacjach rosyjskojęzycznych rola USA w dozbrajaniu Gruzji jest oczywiście wyolbrzymiana. W mojej opinii pomijanie faktów, które świadczą o tym, że Tbilisi nie było tylko biernym uczestnikiem wydarzeń 2008 roku, a również przygotowywało się do konfliktu korzystając z pomocy międzynarodowej, jest niedopuszczalne.

Ponadto, Autor obarcza całkowitą i wyłączną winą za rozpoczęcie konfliktu Rosję, twierdząc, iż Gruzja była zbyt słabym państwem, by zdobyć się na jakiekolwiek prowokacje (s. 142). Twierdzenia takiego nie znajdziemy jednak w innych publikacjach dotyczących omawianego tematu. Zgodnie z Raportem specjalnej komisji Unii Europejskiej o wojnie w Gruzji z 30 września 2009 roku - zarówno Rosjanie, Gruzini, jak i Południowi Osetyjczycy złamali międzynarodowe prawo humanitarne. Jednak wojnę rozpoczęła Gruzja, atakując Cchinwali ciężką artylerią. Inną kwestią jest sprawa odpowiedzialności za konflikt. W tym miejscu autorzy oscylują zazwyczaj bliżej strony rosyjskiej. Wspomina się o wcześniejszych prowokacjach, kwestiach energetycznych i polityce „odmrażania konfliktów”. Problemy te zostały przedstawione również przez I. Matcharashvilego. Charakterystyczną cechą publikacji dotyczących konfliktu w Gruzji jest to, że im później książka została wydana, tym bardziej szala odpowiedzialności przesuwa się w stronę centrum. Wyjątkiem jest większość publikacji ro- 
syjskojęzycznych, w których temat ten jest bardziej ograniczony, podkreślane są prowokacje gruzińskie i prześladowanie ludności Osetii Południowej.

Autorowi można zarzucić także zbytnią powierzchowność i ogólnikowość, która jest generalnym problemem publikacji dotyczących wojny w Gruzji. Większość autorów skupia się bowiem na opisie całości konfliktu, a nie wybranych aspektach, co powoduje, że niektóre kwestie zostają potraktowane zbyt wąsko. I. Matcharashvili bardzo mało uwagi poświęca np. problemowi Adżarii czy casusowi Kosowa. Sytuacja w Kosowie natomiast w opinii m.in. R. Grodzkiego i R. D. Amusa odegrała istotną rolę w abchaskim i osetyjskim dążeniu do niepodległości i zmianie polityki Moskwy w stosunku do Gruzji.

Należy także zaznaczyć, iż publikacja I. Matcharashvilego nie jest skierowana do laików w sprawie sytuacji na Kaukazie. Brak bowiem w tekście i przypisach informacji wyjaśniających niektóre procesy (np. istotę Rewolucji Róż czy wspomnianej wcześniej kwestii Adżarii). Nie ma również odesłania do innych publikacji na ten temat, gdzie czytelnik mógłby uzupełnić braki w wiedzy.

Relacja z samych dni, godzin konfliktu jest precyzyjna, ale dla miłośnika opisów działań wojennych mało szczegółowa. Charakterystyka samego konfliktu zajmuje bowiem mało miejsca w publikacji - biorąc pod uwagę strukturę książki, jest to niecałe 10 procent. Autor mógłby pokusić się o bardziej obszerny opis, wyjaśniający przy tym przede wszystkim istotę działań, ich strategiczne znaczenie, a nie tylko wymieniać poszczególne starcia i jednostki wojskowe w nich użyte. Czytelnika może dziwić skromny opis działań wojennych, choćby z tego powodu, że w publikacji Konflikt kaukaski w 2008 r., I. Matcharashvili opisał szczegółowo działania wojsk gruzińskich. Szkoda, że opisu tego nie poszerzył o opis wojsk rosyjskich i nie załączył do swojej publikacji.

Zamieszczone na końcu książki aneksy mają być próbą ukazania konfliktu od „ludzkiej strony” (s. 13). Znajdują się tu m.in. opisy epizodów wojny, relacje gruzińskich jeńców wojennych. W aneksach znajdziemy także spis jednostek wojskowych Rosji, spis obywateli rosyjskich w rządzie Osetii w latach 2004-2008, opis działania rosyjskiego wywiadu, charakterystykę przemysłu zbrojeniowego Gruzji, analizę aktualnej sytuacji militarno-politycznej między Gruzją a Rosją na rok 2012. Można śmiało stwierdzić, że wszystko to, co nie pasowało do rozdziałów, a dotyczyło konfliktu gruzińsko-rosyjskiego, Autor umieścił w aneksach. Część aneksów ma charakter reportażowy - są emocjonalne i subiektywne; część to suchy spis nazwisk; a jeszcze inna część - to rzetelna analiza stanu obecnego.

Zaletą publikacji jest to, iż I. Matcharashvili nie poświęca zbyt dużo uwagi kwestiom historycznym. Unika tu błędu R. Grodzkiego, który w swojej publikacji kilkadziesiąt stron poświęca przedstawieniu ogólnych informacji o Gruzji. Autor skupia się wyłącznie na wydarzeniach prowadzących bezpośrednio do wojny 2008 roku. Mocną stroną książki jest także przedstawienie procesu „osaczania” Gruzji przez Rosję, poprzez naciski ekonomiczne, prowokacje oraz wykazanie, iż wojna była szczegółowo zaplanowana już kilka lat wcześniej. Podobny opis 
znajdujemy także w publikacji E. Cornella i F. Starra, ci jednak skupiają się także na relacji M. Saakaszwilego na rosyjskie przygotowania przed 2008 rokiem. Należałoby zastanowić się, dlaczego informacje tego typu nie pojawiają się w recenzowanej książce.

Ciekawe, choć wtórne informacje, można znaleźć w rozdziałach dotyczących charakterystyki sił zbrojnych oraz strat wojennych. Dane dotyczące uzbrojenia zostały przedstawione $\mathrm{w}$ sposób przejrzysty i mają za zadanie pomóc czytelnikowi porównać wojska biorące udział w wojnie. Analiza strat wojennych w mojej opinii, zajmuje trochę zbyt dużo miejsca w publikacji, ale została ona sporządzona w sposób rzetelny. Podanie kilku źródeł informacji odnoście zestrzelonych rosyjskich myśliwców i puenta, że prawda może leżeć gdzieś pośrodku (s. 118) świadczą o próbie obiektywizmu Autora. Interesującym rozwiązaniem jest także zamieszczenie informacji dotyczących zmian w siłach zbrojnych poszczególnych stron konfliktu. Zabieg ten ukazuje, w jaki sposób konflikt wpłynął na myślenie obronne Rosji, Gruzji, Abchazji i Osetii Południowej.

$\mathrm{Na}$ uwagę zasługuje również ostatni rozdział stanowiący świadectwa, relacje, opinie. Został on napisany w formie pytań i odpowiedzi, co urozmaica strukturę publikacji. Rozdział ten stanowi absolutne novum w publikach dotyczących wojny w Gruzji. Pierwsze pytanie dotyczy tego, czy Rosjanie wtargnęli do Gruzji 7 sierpnia przed 23:35. Autor powołując się na prasę rosyjską i nagrania rozmów, udziela jednoznacznie potwierdzającej odpowiedzi. Drugie pytanie dotyczy tego, kto strzelił pierwszy. Autor polemizuje w tym miejscu z raportem wydanym przez Komisje Europejską. Ostatnie pytanie dotyczy ostrzelania Cchinwali z rakiet Grad i odpowiedzialności za ten czyn. Odpowiadając na trzy pytania, Autor opiera się zarówno na danych gruzińskich, jak i rosyjskich. Dzięki temu udzielone przez niego odpowiedzi można uznać za prawdziwe.

Resumując powyższe rozważania, trzeba stwierdzić, że książka Irakliego Matcharashvilego 2008 rok, Wojna rosyjsko-gruzińska. Wojna która nie wstrzqsnęła światem jest publikacją, do której należy zajrzeć. Jest to pierwsza praca dotycząca konfliktu rosyjsko-gruzińskiego na polskim rynku wydawniczym, prezentująca gruzińskie spojrzenie na wojnę. Fakt ten jest chyba ważnym powodem, dla którego warto po nią sięgnąć. Choć praca nie przytacza żadnych nowych faktów, a jest w zasadzie powtórzeniem tego, co znamy z innych publikacji o wojnie gruzińskiej. Jedynym oryginalnym posunięciem Autora było opublikowanie wspomnień i relacji świadków wojny w Gruzji, dzięki czemu książka I. Matcharashvilego prezentuje inne - dotąd nieprzedstawione, spojrzenie na konflikt rosyjsko-gruziński.

W publikacji brakuje przede wszystkim analizy wydarzeń politycznych. Nie znajdziemy w niej także charakterystyki otoczenia międzynarodowego, które, jak sugeruje podtytuł, powinno być jednym z najważniejszych elementów publikacji. Książka nie wyczerpuje problematyki wojny rosyjsko-gruzińskiej 2008 roku, a tylko naświetla niektóre jej aspekty. Nie jest także publikacją zbyt obiektywną. 
Zgodnie z założeniami Autora przedstawia gruzińską wersję wydarzeń. Bardziej wymagającym czytelnikom, szukającym szczegółowej analizy dotyczącej wojny gruzińskiej polecam inne publikacje.

Natalia Olszanecka

Uniwersytet Mikołaja Kopernika

w Toruniu

\section{0 fińskich innowacji społecznych, red. Ilkka Taipale, Wy- dawnictwo Szara Godzina, Warszawa-Katowice 2013}

Finlandia to kraj, którym Polacy zaczynają interesować się coraz częściej. Organizowane są festiwale filmowe, wystawy, na naszym rynku wydawniczym pojawiają się też książki fińskich pisarzy. Ostatnio zaś ukazała się praca pod redakcją Ilkki Taipalego 100 finskich innowacji społecznych ${ }^{1}$. Stanowi ona zbiór stu krótkich artykułów, których autorami są wybitni przedstawiciele życia politycznego, społecznego, naukowego i gospodarczego tego kraju. Podzielono ją na sześć odrębnych działów: administracja państwowa, polityka społeczna, społeczeństwo obywatelskie, sprawy regionalne, kultura, służba zdrowia, tworząc równocześnie swego rodzaju ranking działań określonych mianem społecznych innowacji.

Trzeba przyznać, że termin ten wzbudzać może wątpliwości, gdyż na ogó1 kojarzymy go z wynalazczością, techniką, gospodarką, a nie z kwestiami społecznymi, jednak ostatnio pojawia się on często w publicystyce i jest dość powszechnie używany. Odniósł się do tego w swojej przedmowie do książki prezydent Finlandii Sauli Niinistö: [...] Okazuje sie jednak, że innowacje mogq mieć także charakter społeczny. Dostępne obywatelom innowacje społeczne stanowiq praktyczne rozwiqzania, które promuja ich aktywność, podnoszq stope życiowa, poprawiaja stan zdrowia, wyksztatcenie i ogólny dobrobyt [...] (s. 9).

Wydaje się, że tak naprawdę nie są to rozwiązania spowodowane tylko samą chęcią wdrażania nowości i poprawiania jakości życia, ale w dużym stopniu wynikają one z tradycji, kultury czy historii tego kraju. Zapewne $\mathrm{z}$ tego powodu praca ta nie cieszyła się w Finlandii szczególną popularnością, uznano ją za mało ciekawą i zawierającą treści powszechnie znane i oczywiste, natomiast w innych krajach stała się przedmiotem dyskusji oraz przyczynkiem do porównań2. Podobnie jest też z polskim wydaniem, które zwróciło uwagę zarówno czytelników, jak i mediów.

1 Ilkka Taipale jest doktorem nauk medycznych, posłem do parlamentu (Eduskunta) w latach 1971-1975 oraz 2000-2007, a także znanym działaczem społecznym i współautorem prezentowanej pracy.

2 Książka została przetłumaczona na kilkanaście języków, m.in. na tak egzotyczne, jak: mandaryński, urdu, pendżabski, a spodziewane są tłumaczenia na bengalski, perski, hindi. 